\title{
Cushing's Syndrome due to Bilateral Adrenocortical Adenomas with Different Pathological Features
}

\author{
Hideki Tamura, Hitoshi Sugihara, Shiro Minami, Naoya Emoto, Tamotsu Shibasaki, \\ Yujin Shuto, Kazuo Shimizu*, Yukari Gomi**, Hironobu SaSAno*** and Ichiji WaKabayashi
}

A 48-year-old woman with Cushing's syndrome due to bilateral adrenocortical adenomas is reported. The patient presented with a typical Cushingoid appearance. The serum cortisol level was elevated with loss of the diurnal rhythm and the plasma adrenocorticotropic hormone (ACTH) level was undetectable. Dynamic testing showed no suppression of urinary 17-OHCS by high-dose dexamethasone and no stimulation by metyrapone. An abdominal computed tomography (CT) scan showed bilateral adrenal tumors. Bilateral adrenalectomy was performed. The right adrenal gland contained a tumor that was encapsulated and consisted mainly of compact cells. The surrounding cortex was atrophic. The left adrenal gland contained an encapsulated tumor composed predominantly of clear cells. There were numerous small adrenocortical nodules in the surrounding cortex. Immunohistochemical analysis of steroidogenic enzymes (P450scc, 3 $\beta$-HSD, $\mathrm{P450c21}$, P450c17 and $\mathrm{P450c11}$ ) was performed. Immunoreactivity of all the enzymes was intense in the compact cells of the right adrenocortical adenoma, while the adjacent non-neoplastic cortex was negative for the enzymes. In the left adrenal tumor, the immunoreactivity of 3 $\beta$-HSD was intense, while that of P450c17 was weak. In the adrenocortical nodules, $3 \beta$-HSD activity was sporadically observed. G protein genes encoding Gs $\alpha$ and Gi2 were examined for activating mutations at codons 201 and 227 (Gs $\alpha$ ) and codons 179 and 205 (Gi2 $\alpha)$ in the bilateral adrenal tumors, but no mutations were found. The bilateral adenomas of this patient showed marked differences in microscopic and immunohistochemical studies, suggesting that the capacity of steroidogenesis differs between the right and left tumors.

(Internal Medicine 36: 804-809, 1997)

Key words: immunohistochemistry, G protein gene mutation

\section{Introduction}

Endogenous Cushing's syndrome can be divided into two general types: adrenocorticotropic hormone (ACTH)-dependent and ACTH-independent. The majority of ACTH-independent Cushing's syndrome is due to a unilateral adrenocortical lesion. ACTH-independent Cushing's syndrome is occasionally caused by bilateral adrenocortical lesions. These include primary pigmented nodular adrenocortical disease (PPNAD), ACTH-independent bilateral macronodular adrenocortical hyperplasia (AIMAH) and bilateral adrenocortical tumors. The endocrine and pathologic features of PPNAD and AIMAH have been well documented (1-6). However, the pathogenesis of bilateral adrenocortical adenomas appears to be heterogeneous (7-13). In the present case, diagnosed as
Cushing's syndrome due to bilateral adenomas, microscopic studies and immunohistochemical studies for steroidogenic enzymes showed marked differences between the right and left tumors.

In the past few years, mutations in $\mathrm{G}$ proteins have been identified as the causes of several endocrine diseases (14). G protein genes encoding Gs $\alpha$ and Gi2 were also examined for activating mutations at codons 201 and 227 (Gs $\alpha$ ) and codons 179 and 205 ( Gi2 $\alpha$ ) in the adrenal tumor tissues.

\section{Case Report}

A 48-year-old woman was hospitalized because of Cushingoid appearance. For several years, she had been amenorrheal and was being treated for hypertension. She had

\footnotetext{
From the Third Departments of Medicine and *Second Surgery, Nippon Medical School, Tokyo, **Itoh Hospital, Tokyo, ***the Department of Pathology, Tohoku University School of Medicine, Sendai

Received for publication November 1, 1996; Accepted for publication July 10, 1997

Reprint requests should be addressed to Dr. Hideki Tamura, the Department of Medicine, Nippon Medical School, 1-1-5 Sendagi, Bunkyo-ku, Tokyo 113
} 
gained $17 \mathrm{~kg}$ over the last 5 years. Dependent edema had been noted for 2 years. The laboratory data were consistent with ACTH-independent Cushing's syndrome, as described below. She was referred to the Nippon Medical School Hospital in January 1995 . She had undergone thyroidectomy for papillary carcinoma of the thyroid 5 years earlier. Her mother died of lung cancer.

The patient's height was $163 \mathrm{~cm}$, and her body weight was $84 \mathrm{~kg}$. The blood pressure was $128 / 70 \mathrm{mmHg}$ while she was on an antihypertensive drug. She had central obesity, moon face, thin skin, easy bruisability, striae cutis, hirsutism and pitting edema of the lower extremities. There was no cutaneous hyperpigmentation or spotty pigmentation. Radiographs of the chest showed mild cardiomegaly, while those of the thoracic and lumbar vertebrae revealed osteoporosis.

The initial laboratory data were as follows. The white blood cell count was 11,300 per cubic millimeter with a shift to the left, and $0 \%$ eosinophils. In addition, serum potassium was 3.6 $\mathrm{mEq} / l$, fasting blood glucose $79 \mathrm{mg} / \mathrm{dl}$, morning serum cortisol $31 \mu \mathrm{g} / \mathrm{dl}$, morning plasma ACTH not detectable (lower than 5 $\mathrm{pg} / \mathrm{ml}$ ), urinary cortisol $414 \mu \mathrm{g} / \mathrm{day}$ (normal $20-100 \mu \mathrm{g} / \mathrm{day}$ ), serum dehydroepiandrosterone sulfate $626 \mathrm{ng} / \mathrm{ml}$ (normal 500 2,500 ng/ml), plasma renin activity $1.1 \mathrm{ng} / \mathrm{ml} / \mathrm{h}$, and serum aldosterone $4.2 \mathrm{ng} / \mathrm{dl}$. The results of endocrine studies of the hypothalamic-pituitary-adrenal axis are shown in Table 1 . The diurnal rhythm of serum cortisol was lost. The urinary 17OHCS did not respond to the administration of dexamethasone or metyrapone (Table 1). Administration of $100 \mu \mathrm{g}$ of human corticotropin-releasing hormone $(\mathrm{CRH})$ did not influence the level of serum cortisol or plasma ACTH (lower than $5 \mathrm{pg} / \mathrm{ml}$ ). Oral administration of $75 \mathrm{~g}$ of glucose also did not influence the serum cortisol level (Table 1). Computed tomography (CT) scans of the abdomen showed bilateral adrenal tumors (Fig. 1), while CT scans of the sella turtica revealed nothing remarkable. An iodocholesterol scintigram showed bilateral adrenal activity (Fig. 2).

On February 1995, bilateral total adrenalectomy was performed. The right adrenal gland weighed $6.8 \mathrm{~g}$ and contained an oval-shaped brown tumor $(3.5 \times 2.8 \mathrm{~cm})$ (Fig. 3). The tumor was encapsulated and consisted mainly of compact cells (Fig. 4A), while the surrounding cortex was atrophied (Fig. 4B). The left adrenal gland weighed $5.8 \mathrm{~g}$ and contained a round tumor $(2.4$ $\times 2.2 \mathrm{~cm}$ ) (Fig. 3). The major tumor was encapsulated and composed predominantly of clear cells (Fig. 4C). The surrounding cortex contained numerous small adrenocortical cell nodules, and intervening adrenocortical tissue was not clearly found (Fig. 4D). Microscopic examination confirmed that the bilateral tumors were benign adrenocortical adenomas. Since the bilateral adrenalectomy, the patient has been on dexamethasone $(0.5 \mathrm{mg} / \mathrm{day})$ or prednisolone $(5 \mathrm{mg} / \mathrm{day})$. The plasma ACTH level has been below or only slightly above the limit of detection of the assay $(5 \mathrm{pg} / \mathrm{ml})$.

Immunohistochemical analyses of the following steroidogenic enzymes [cholesterol side chain cleavage ( $\mathrm{P} 450 \mathrm{scc}), 3 \beta$ -

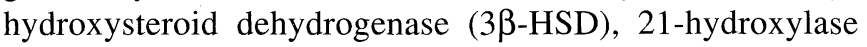
(P450c21), 17 $\alpha$-hydroxylase (P450c17) and 11 $\beta$-hydroxylase (P450c11)] were performed according to the methods described previously (13). Immunoreactivity of all the enzymes

Table 1. Results of Endocrine Studies of Pituitary-Adrenal Axis

\begin{tabular}{|c|c|c|c|c|c|}
\hline & $\begin{array}{l}\text { Serum cortisol } \\
\qquad(\mu \mathrm{g} / \mathrm{dl})\end{array}$ & \multicolumn{2}{|c|}{$\begin{array}{l}\text { Serum 11-deoxy- } \\
\text { cortisol }(\mu \mathrm{g} / \mathrm{dl})\end{array}$} & $\begin{array}{c}\text { Urine } 17-\mathrm{OHCS} \\
\text { (mg/day) }\end{array}$ & $\begin{array}{c}\text { Urine } 17-\mathrm{KS} \\
\text { (mg/day) }\end{array}$ \\
\hline \multicolumn{6}{|c|}{ Dexamethasone suppression test ${ }^{\dagger}$} \\
\hline basal level (day 1) & & & \multicolumn{2}{|r|}{14.5} & 13.4 \\
\hline 4 mg/day (day 2) & & & & & \\
\hline 4 mg/day (day 3) & & & \multicolumn{2}{|r|}{18.8} & 21.5 \\
\hline \multicolumn{6}{|l|}{ Metyrapone test ${ }^{\ddagger}$} \\
\hline basal level (day 1) & \multirow{3}{*}{26.5} & \multirow{2}{*}{\multicolumn{2}{|c|}{9.9}} & 46.8 & 31.8 \\
\hline basal level (day 2) & & & & 29.1 & 17.4 \\
\hline $4.5 \mathrm{~g} /$ day (day 3 ) & & & \multicolumn{2}{|r|}{27.3} & 20.9 \\
\hline 1-day late (day 4) & 6.1 & \multicolumn{2}{|c|}{76.5} & 21.6 & 14.9 \\
\hline & $0 \mathrm{~min}$ & $15 \mathrm{~min}$ & $30 \min$ & $60 \mathrm{~min}$ & $120 \mathrm{~min}$ \\
\hline \multicolumn{6}{|l|}{ CRH test* } \\
\hline cortisol $(\mu \mathrm{g} / \mathrm{dl})$ & 30.9 & 32.4 & 32.1 & 33.6 & \\
\hline $\mathrm{ACTH}(\mathrm{pg} / \mathrm{ml})$ & $<5$ & $<5$ & $<5$ & $<5$ & \\
\hline \multicolumn{6}{|l|}{ Oral glucose $\mathrm{e}^{\S}$} \\
\hline cortisol $(\mu \mathrm{g} / \mathrm{dl})$ & 32.2 & 32.7 & 33.9 & 31.9 & 35.4 \\
\hline
\end{tabular}



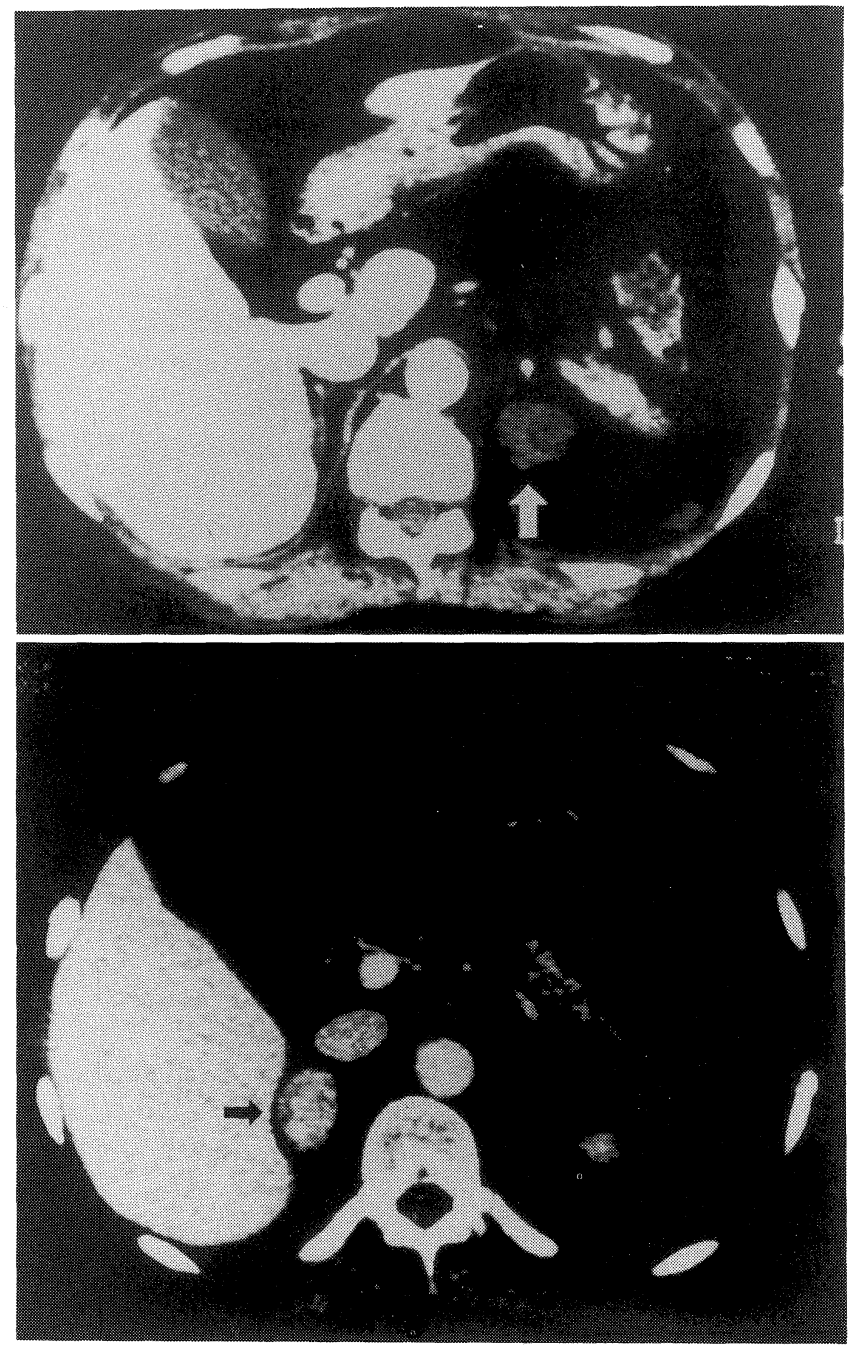

Figure 1. Abdominal CT showing left (upper panel) and right (lower panel) adrenal glands (arrows).

was intense in the compact cells of the right adrenocortical adenoma, while it was negative in the adjacent non-neoplastic cortex. Immunoreactivity of all the steroidogeneic enzymes was also detected in the major left adrenal tumor, with marked $3 \beta$-HSD and weak P450c17 immunoreactivity (Figs. 5, 6). In the adrenocortical nodules, $3 \beta$-HSD immunoreactivity was sporadically observed (Fig. 5).

Genomic DNA from the bilateral tumor tissues obtained at the time of surgery was extracted by standard procedures. DNA was amplified by the polymerase chain reaction (PCR) with 2 sets of primers flanking codons 201 and 227 of the human Gs $\alpha$ gene and codons 179 and 205 of the human Gi2 $\alpha$ gene (14). The PCR mixture contained 2.5 U Taq DNA polymerase and 30 pmol of each primer. Amplification was accomplished in 30 cycles of 1 minute at $94^{\circ} \mathrm{C}, 2$ minutes at $58^{\circ} \mathrm{C}$ and 3 minutes at $72^{\circ} \mathrm{C}$ in a Perkin-Elmer Cetus Thermocycler. Amplified DNA was purified and subjected to direct DNA sequence using the Sequenase kit (U.S. Biochemicals, Cleveland, OH). Genomic DNA from each tumor showed only the wild-type sequence at

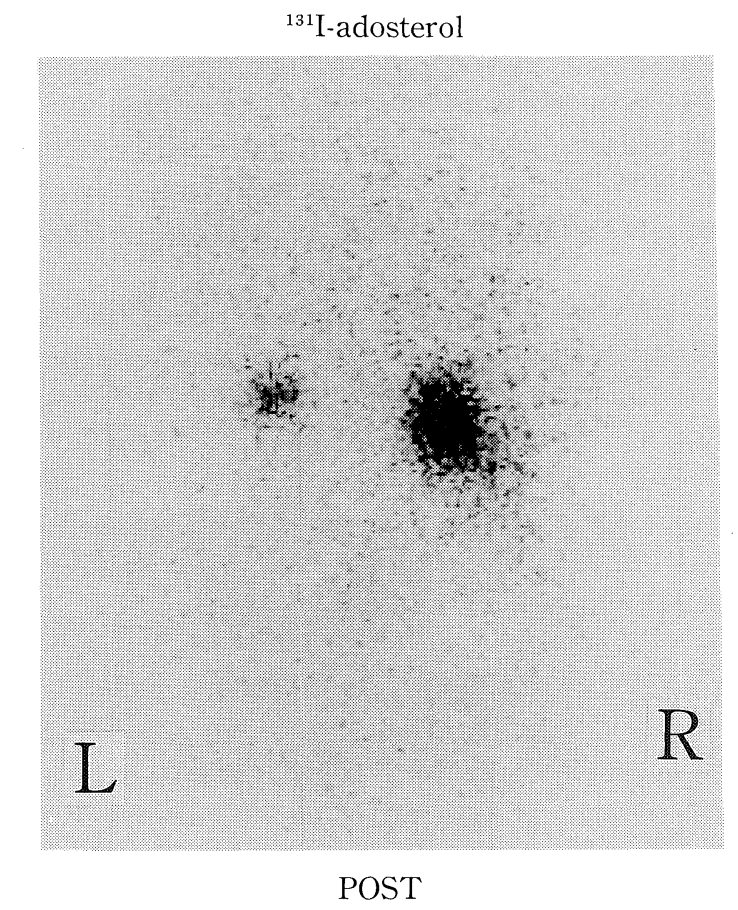

Figure 2. Adrenal scintigram using ${ }^{131}$ I-adosterol showed bilateral uptake of the tracer.

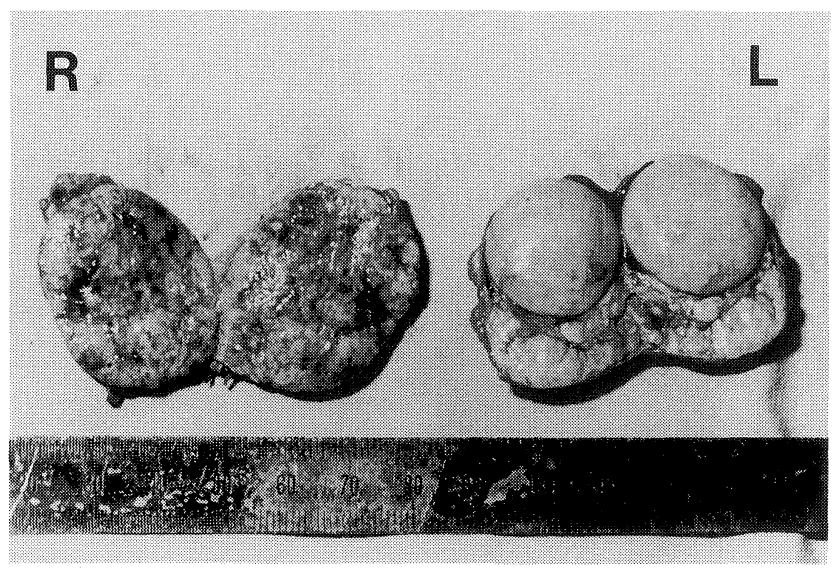

Figure 3. Macroscopic appearances of the cross-sections of right and left adrenal glands.

codons 201 and 227 of the human Gs $\alpha$ gene. We then looked for mutations of the human Gi2 $\alpha$ gene. No mutations were found in codon 179 or codon 205 of the human Gi2 $\alpha$ gene.

\section{Discussion}

Bilateral adrenal adenomas causing Cushing's syndrome in the present case showed marked differences between the right and left tumors in the histological studies and immunohistochemical studies for steroidogenic enzymes. The features of the 
right adrenal adenoma were typical of ACTH-independent adrenal adenomas causing Cushing's syndrome. In contrast, the

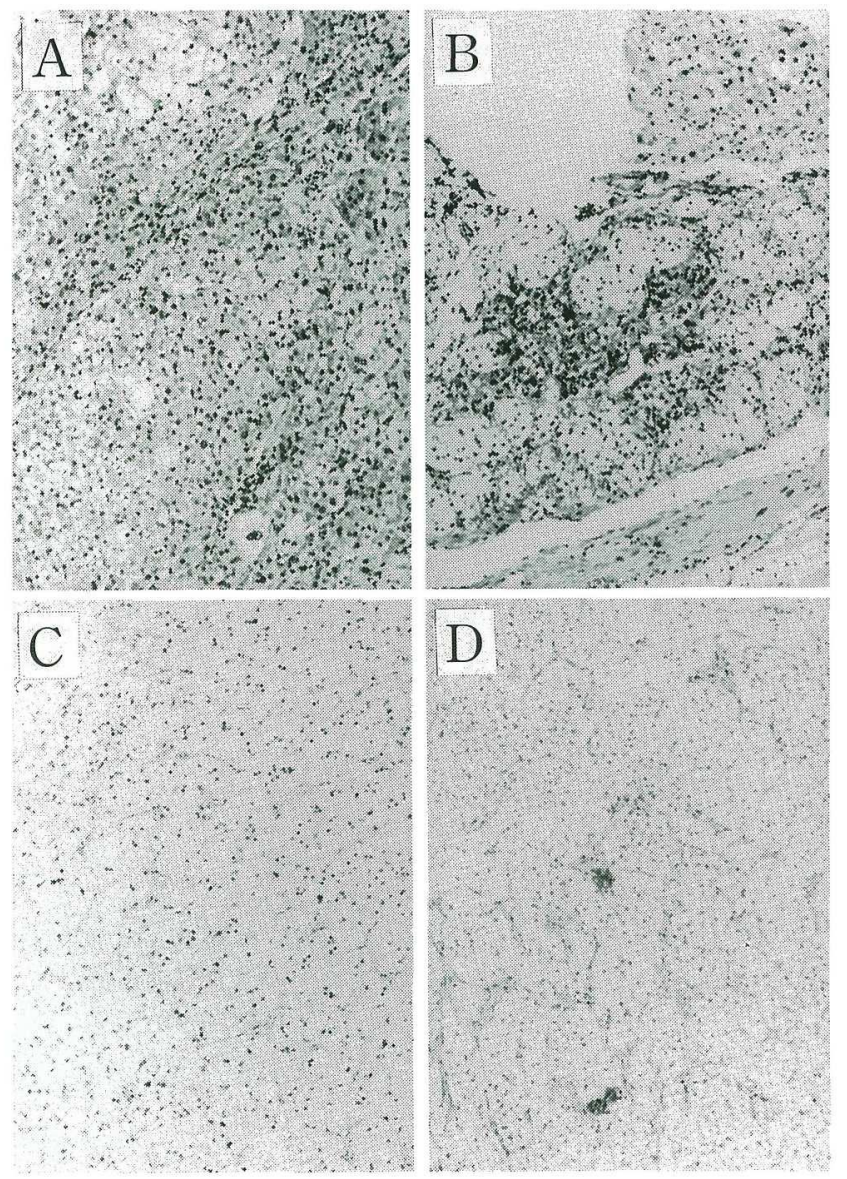

left adrenal gland harbored one large adenoma which showed different histological features and patterns of expression of steroidogenic enzymes compared to the right adrenal tumor. In addition, numerous small adrenocortical nodules expressing steroidogenic enzymes existed, and the intervening cortical tissues were not found in the left adrenal. It is speculated that, in this patient, the right adrenocortical adenoma might efficiently produce and dominantly secrete cortisol as compared to the left adrenal tumor. These features of bilateral adenoma of our patient are clearly different from those described for PPNAD or AIMAH. For instance, in AIMAH, the histological features reveal a combination of cord-forming clear cells and nestforming compact cells (15), and P450c17 and 33-HSD are weakly expressed in the clear cells and compact cells, respectively (2-4). In PPNAD, the adrenal cortex consists mainly of compact cells with dispersed micronodules which strongly express all steroidogenic enzymes (1).

Bilateral macronodular hyperplasia is found in older patients with long-standing Cushing's disease (16). The nodules compress the surrounding cortex, which is, without exception, hyperplastic. A transition from pituitary-dependent to ACTH independent solitary adrenocortical adenoma has been postulated (17). It is still uncertain whether there is ever progression

Figure 4. HE-stained sections of the right adrenal glands (A, B) $(\times 150)$. The tumor consisted mainly of compact cells $(A)$, the surrounding cortex was atrophic $(B)$. HE-stained sections of the left adrenal glands $(C, D)(\times 150)$. The major tumor was encapsulated predominantly composed of clear cells $(\mathrm{C})$, while adrenocortical nodules in the surrounding cortex were also composed of clear cells (D).

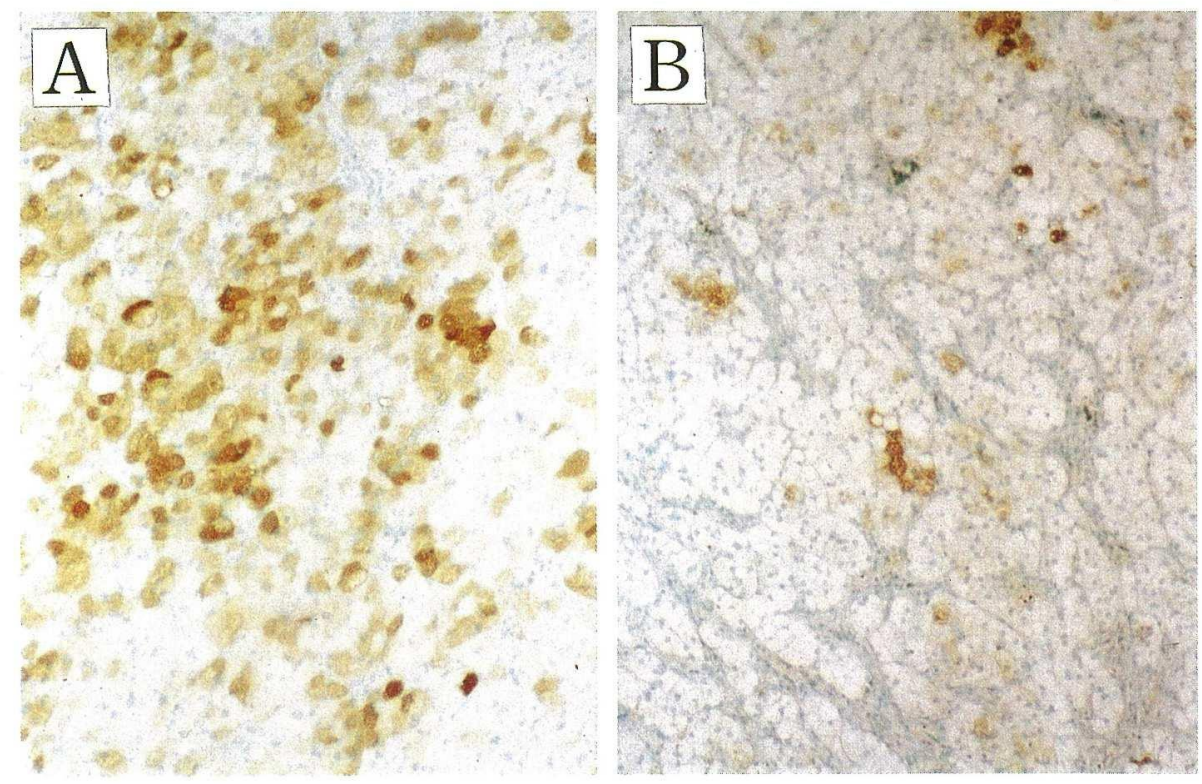

Figure 5. Immunoreactivity of $3 \beta$-HSD in the left adrenal gland $(\times 200)$. Intense immunoreactivity was observed in the tumor (A), but sporadically expressed in the attached nodules (B). 


\section{TAMURA et al}
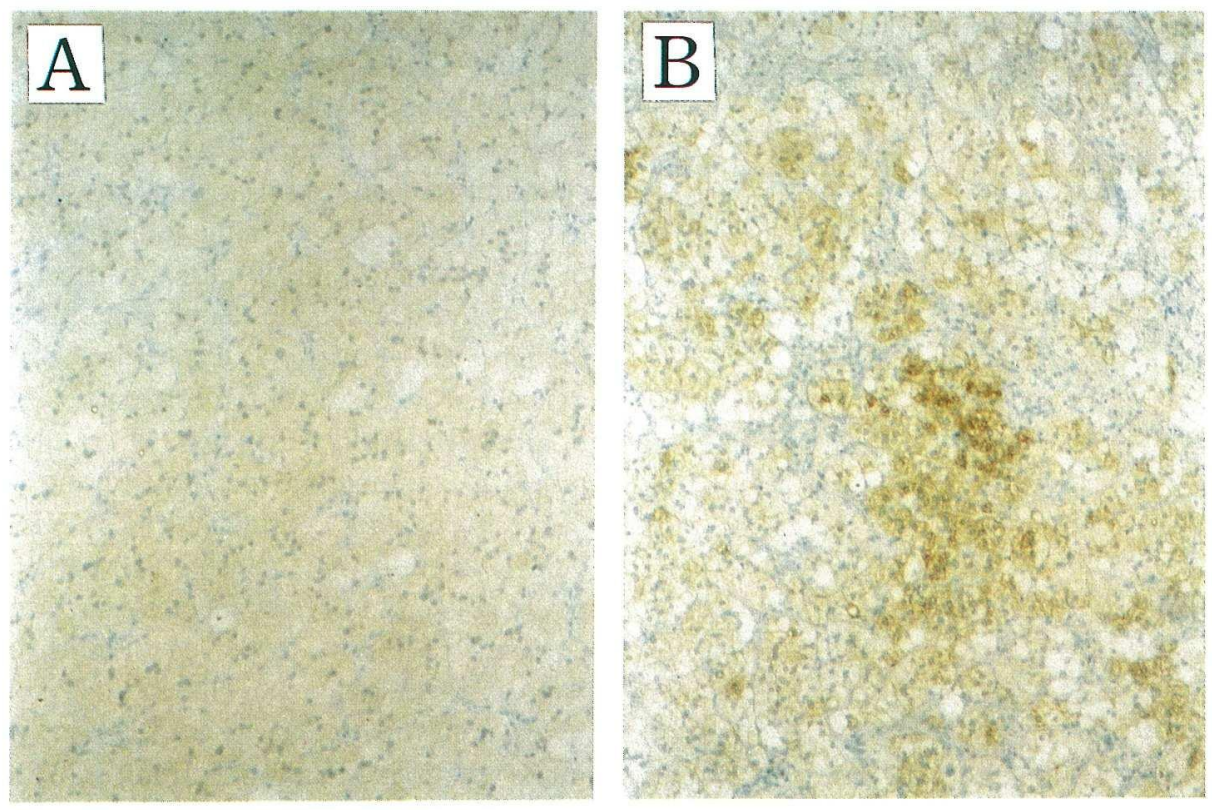

Figure 6. Immunoreactivity of P450c17 in the left adrenal gland $(\times 200)$. Immunoreactivity in the attached adrenocortical nodules was intense (A), but it was weak in the adrenal tumor (B).

to true autonomy. Other mechanisms have been proposed for the development of bilateral adrenocortical adenomas or nodular adrenal hyperplasia. An aberrant adrenal sensitivity to gastric inhibitory polypeptide (GIP) underlies Cushing's syndrome with nodular adrenal hyperplasia $(18,19)$. This does not appear to apply to this case, since the plasma cortisol did not increase in response to oral glucose administration accompanying the increased GIP secretion $(18,19)$.

$\mathrm{G}$ protein mutations occur in a wider range of endocrine conditions than has been recognized hitherto (20). Activating mutations of the $\alpha$-subunits of Gs and Gi2 $\alpha$ that convert these subunits into putative oncogenes have been described in patients with multiple endocrinopathies, including nodular and hyperplasic adrenal glands accompanied by pituitary adenoma (14). However, we could not detect activating mutations at codons 201 and 227 of the Gs $\alpha$ subunit or codons 179 or 205 of the Gi2 $\alpha$ subunit in the tumor tissue from the present case.

\section{References}

1) Sasano H, Miyazaki S, Sawai T, et al. Primary pigmented nodular adrenocortical disease (PPNAD): immunohistochemical and in situ hybridization analysis of steroidogenic enzymes in eight cases. Mod Pathol 5: 23, 1992.

2) SasanoH, Suzuki T, Nagura H. ACTH-independent macronodular adrenocortical hyperplasia: immunohistochemical and in situ hybridization studies of steroidogenic enzymes. Mod Pathol 7: 215, 1994.

3) Aiba M, Hirayama A, Iri H, et al. Adrenocorticotropic hormone-independent bilateral adrenocortical macronodular hyperplasia as a distinct subtype of Cushing's syndrome. Enzyme histochemical and ultrastructural study of four cases with a review of the literature. Am J Clin Pathol 96: 334, 1991.

4) Aiba M, Hirayama A, Iri H, et al. Primary adrenocortical micronodular dysplasia: enzyme histochemical and ultrastructural studies of two cases with a review of the literature. Hum Pathol 21: 503, 1990.

5) Young WF Jr, Carney JA, Musa BU, Wulffraat NM, Lens JW, Drexhage HA. Familial Cushing's syndrome due to primary pigmented nodular adrenocortical disease: reinvestigation 50 years later. $\mathbf{N}$ Engl $\mathbf{J}$ Med 321: $1659,1989$.

6) Kirschner MA, Powell RD, Lipsett MB. Cushing's syndrome: nodular cortical hyperplasia of adrenal glands with clinical and pathological features suggesting adrenocortical tumor. J Clin Endocr 24: 947, 1964.

7) Kato K, Horio S, Nonoyama M, et al. A case of Cushing's syndrome due to bilateral multiple adrenocortical adenomas. Horumon Rinsho 24: 145, 1976 (in Japanese).

8) Mimou N, Sakato S, Nakabayashi H, Saito Z, Takeda R, Matsubara F. Cushing's syndrome associated with bilateral adrenal adenomas. Acta Endocrinol (Copenh) 108: 245, 1985.

9) Okamoto S, Oosumi T, Fujimoto M, et al. Cushing's syndrome due to bilateral adrenal adenoma. Horumon Rinsho 33: 691, 1985 (in Japanese).

10) Nakata $K$, Hayakawa M, Yokono K, et al. A case of Cushing's syndrome due to bilateral adrenocortical adenomas. Jpn J Int Med 75: 528, 1986.

11) Satoh K, Miyagata S, Harata T, Nishizawa O, Tsutida S. A case report of Cushing's syndrome due to bilateral adrenal adenomas. Nippon Hinyokika Gakkai Zasshi 79: 1463, 1988.

12) Kato $S$, Masunaga R, Kawabe T, et al. Cushing's syndrome induced by hypersecretion of cortisol from only one of bilateral adrenocortical tumors. Metabolism 41: 260, 1992.

13) Aiba M, Kawakami M, Ito $Y$, Fujimoto $Y$, Suda $T$, Demura H. Bilateral adrenocortical adenomas causing Cushing's syndrome: report of two cases with enzyme histochemical and ultrastructural studies and a review of the literature. Arch Pathol Lab Med 116: 146, 1992.

14) Williamson EA, Johnson SJ, Foster S, Kendall-Taylor P, Harris PE. G protein gene mutations in patients with multiple endocrinopathies. J Clin Endocrinol Metab 80: 1702, 1995.

15) Koizumi S, Beniko M, Ikota A, et al. Adrenocorticotropic hormoneindependent bilateral adrenocortical macronodular hyperplasia: a case report and immunohistochemical studies. Endocr J 41: 429, 1994.

16) Smals AGH, Pieters GF, Van Haelst UJ, Kloppenborg PW. Macronodular adrenocortical hyperplasia in long-standing Cushing's disease. J Clin 


\section{Cushing's Syndrome due to Adrenal Adenomas}

Endocrinol Metab 58: 25, 1984.

17) Schteingart DE, Tsao HS. Coexistence of pituitary adrenocorticotropindependent Cushing's syndrome with a solitary adrenal adenoma. J Clin Endocrinol Metab 50: 961, 1980.

18) Lacroix A, Bolté E, Tremblay J, et al. Gastric inhibitory polypeptidedependent cortisol hypersecretion: a new cause of Cushing's syndrome. N Engl J Med 327: 974, 1992.
19) Reznik Y, Allali-Zerah V, Chayvialle JA, et al. Food-dependent Cushing's syndrome mediated by aberrant adrenal sensitivity to gastric inhibitory polypeptide. N Engl J Med 327: 981, 1992.

20) Weinstein LS, Shenker A, Gejman PV, Merino MJ, Friedman E, Spiegel AM. Activating mutations of the stimulatory G protein in the McCuneAlbright syndrome. N Engl J Med 325: 1688, 1991. 